\title{
TEMPORARY EFFECT OF CHISELING ON THE COMPACTION OF A RHODIC HAPLUDOX UNDER NO-TILLAGE(1)
}

\author{
Sâmala Glícia Carneiro Silva ${ }^{(2)}$, Álvaro Pires da Silva( ${ }^{(3)}$, Neyde Fabíola Balarezo \\ Giarola $^{(4)}$, Cássio Antônio Tormena ${ }^{(5)}$ \& João Carlos de Moraes Sá(6)
}

\begin{abstract}
SUMMARY
Mechanical chiseling has been used to alleviate the effects of compaction in soils under no-tillage (NT). However, its effect on the soil physical properties does not seem to have a defined duration period. The purpose of this study was to evaluate the behavior of the bulk density (BD) and degree of compaction (DC) at different soil depths, after chiseling in no-tillage, for one year. The experiment was performed in Ponta Grossa, Paraná State, Brazil, using an Oxisol (Rhodic Hapludox). Bulk density and DC were previously measured in an area under NT for 16 years, then immediately after chiseling (CHI) in May 2009, six months after chiseling (CHI6M) in October 2009 and one year after chiseling (CHI12M) in May 2010. In the layers 0.0-0.10, 0.10-0.20 and 0.20-0.30 m, there was a significant $\mathrm{BD}$ reduction $\mathrm{CHI}$ and a marked increase $\mathrm{CHI} 6 \mathrm{M}$. The BD values measured CHI12M were similar to those before tillage. Chiseling reduced the DC in the layers $0.0-0.10 \mathrm{~m}$ and $0.10-0.20 \mathrm{~m}$, but returned to the initial values one year later. During the evaluation periods CHI, CHI6M and CHI12M, the BD increased in the layer $0.30-0.40 \mathrm{~m}$, compared with NT. The highest DC values were observed six months after chiseling; nevertheless the structural recovery of the soil was considerable, possibly due to the high degree of soil resilience and the influence of the wetting and drying cycles detected in the study period. The chiseling effects, evaluated by BD and DC, lasted less than one year, i.e., the beneficial short-term effects of chiseling on the reduction of the surface BD increased the risk of compaction in deeper soil layers.
\end{abstract}

Index terms: soil compaction, structure, soil quality, resilience.

(1) Part of the Master's Dissertation of the first author. Received for publication in April 1, 2011 and approved in December $22,2011$.

(2) Doctorate Student of Graduate Program in Soils and Plant Nutrition, Escola Superior de Agricultura "Luiz de Queiroz" - ESALQ/ USP). Av. Pádua Dias 11, Caixa Postal 09, CEP 13418-900 Piracicaba (SP), Brazil. E-mail: samalaglicia@gmail.com

(3) Professor of Departament of Soil Science, ESALQ/USP. E-mail: apisilva@usp.br

(4) Professor of Departament of Soil Science and Agricultural Engineering, Universidade Estadual de Ponta Grossa - UEPG. Av. General Carlos Cavalcanti 4748, CEP 84030-900 Ponta Grossa (PR), Brazil. E-mail: neydegiarola@gmail.com

(5) Professor of Departament of Agronomy, Universidade Estadual de Maringá - UEM. Av. Colombo 5790, CEP 87020-900 Maringá (PR), Brazil. E-mail: catormena@uem.br

(6) Professor of Departament of Soil Science and Agricultural Engineering, UEPG. E-mail: jcmsa@uepg.br 


\title{
RESUMO: EFEITO TEMPORAL DA ESCARIFICAÇÃO SOBRE A COMPACTAÇÃO EM LATOSSOLO VERMELHO SOB SISTEMA PLANTIO DIRETO
}

\begin{abstract}
A escarificação mecânica tem sido empregada para amenizar os efeitos da compactação em solos manejados sob sistema plantio direto (SPD). No entanto, não está clara a duração dos seus efeitos sobre as propriedades físicas do solo. O objetivo deste trabalho foi avaliar o comportamento da densidade do solo (Ds) e do grau de compactação $(G C)$ em profundidade após a escarificação do solo sob SPD durante um ano. O experimento localiza-se no município de Ponta Grossa, Paraná, em um Latossolo Vermelho distrófico. Medidas de Ds e GC foram feitas em área sob SPD por 16 anos (PD) e imediatamente após a escarificação (ESC), em maio/2009; seis meses após a escarificação (ESC6M), em outubro/2009; e um ano após a escarificação (ESC12M), em maio/2010. Nas camadas de 0,0-0,10, 0,10-0,20 e 0,20-0,30 m, verificou-se redução significativa da Ds em ESC e aumento expressivo em ESC6M. Em ESC12M, constataram-se valores de Ds similares aos medidos antes da mobilização do solo. A escarificação reduziu o GC nas camadas de 0,0-0,10 e 0,10-0,20 m, com o retorno aos valores originais um ano após a escarificação. Nos períodos ESC, ESC6M e ESC12M foram observados aumentos da Ds na camada de 0,30-0,40 $\mathrm{m}$, em comparação com o $P D$. Os maiores valores de GC foram observados seis meses após a escarificação, porém o solo mostrou grande recuperação estrutural, possivelmente devido ao elevado grau de resiliência do solo e à influência dos ciclos de umedecimento e secagem durante o período estudado. Os efeitos da escarificação, avaliados pela Ds e GC, apresentaram duração inferior a um ano; portanto, possíveis efeitos benéficos da escarificação em reduzir a Ds em superfície, em curto prazo, propiciam aumento dos riscos de compactação do solo em profundidade.
\end{abstract}

Termos de indexação: compactação do solo, estrutura, qualidade do solo, resiliência.

\section{INTRODUCTION}

The no-tillage system (NT) has been increasingly adopted due to the numerous economic and agronomic advantages, such as soil and water conservation and crop yield. Straw accumulation on the soil surface provides a greater amount of organic matter that favors lower water evaporation and improves soil aggregation (Blanco-Canqui et al., 2010). Under NT, there may be compacted layers, mainly down to a depth of $0.2 \mathrm{~m}$, due to the absence of soil tilling and intense machinery traffic over time, favoring the natural reconsolidation of soil particles (Reichert et al., 2003; Håkansson, 2005).

When the applied pressure is higher than its internal resistance, the soil structure becomes compacted and degraded, so that the greater the soil resilience, the lower will be the compaction persistence. Soil tillage operations, such as chiseling, are increasingly used to remove compacted layers that may occur in soils under NT. The efficiency of mechanical decompaction is associated to several factors, e.g., the initial compaction condition, soil moisture at the operation time, soil texture, organic matter content and aspects related to the interactions between soil and implements. Although chiseling may improve the soil physical properties (Camara \& Klein, 2005), there is evidence the effect is short-lived and varies from two months (Xu \& Mermoud, 2001), to one year (Reichert et al., 2009) and even to three years (Busscher et al., 2002).

Soil structure plays an important role in several soil physical processes, such as water movement, aeration and porosity. Thus, practices that modify the soil structure, such as chiseling, should be planned in order to avoid its degradation. Among the processes that influence the durability of the chiseling effects are the intensity of wetting and drying cycles and soil resilience.

The wetting and drying cycles contribute to soil aggregation, affecting its structure. Furthermore, the plant cover influences the magnitude, frequency and effect of these cycles on soil aggregation (Materechera, 1992). The configuration of the porous system is directly related to the intensity and frequency of these cycles, which are more intense in the soil surface layers (up to $0.2 \mathrm{~m}$ ), due to the higher concentration of plant root systems (Horn \& Dexter, 1989; Oliveira et al., 1996).

Resilience is defined as the soil ability to recover its structural and functional integrity after an external disturbance (Seybold et al., 1999). The soil physical resilience consists of a series of regenerative processes that include the wetting and drying cycles and biological activities such as root growth and 
soil fauna movements (Gregory et al., 2007). Under NT, the organic matter increase in the soil surface layers confers a higher soil resilience degree (BlancoCanqui et al., 2009), especially when it is associated with straw due to its high elasticity and low density.

In order to evaluate the chiseling effects, the physical property soil bulk density (BD) is used to characterize the soil compaction condition, as it is able to detect changes in volume and provides a general view of the soil porosity (Silva et al., 1997). However, BD alone is not sufficient to determine the status of the soil physical quality regarding compaction, so that the utilization of some parameters that eliminate differences among soils is necessary (Håkansson \& Lipiec, 2000). Therefore, an indicator of the soil compaction status, identified as the degree of compaction (DC), has been suggested. The DC is based on the relation between the current soil density and a standard soil density, which corresponds to either the reference or the maximum soil density (BDref).

The DC is expressed in percentage and provides a comparison of the compaction status of several soil types, eliminating the interference of the texture. The BDref can be obtained through the Proctor test (Klein et al., 2009; Blanco-Canqui et al., 2009) or through the uniaxial compression test that has, as reference, a pressure of $200 \mathrm{kPa}$ (Håkansson, 1990; Lipiec et al., 1991; Silva et al., 1997). The Proctor test may overestimate the DC, as it results in higher BDref values than those obtained through the uniaxial compression test (Håkansson, 1990; Håkansson \& Lipiec, 2000). The energy applied onto the soil by the Proctor test corresponds to $560 \mathrm{kPa}$, which is almost three times higher than the pressure applied by the uniaxial compression test.

In soils under NT, the high DC values are apparently less detrimental to plant growth (Reichert et al., 2009). However, in Brazil, there is little research that associates the compaction degree to the behavior of the soil physical properties under NT (Suzuki et al., 2007; Reichert et al., 2009), thus more studies are necessary for a better comprehension of the DC dynamics according to the soil management over time. The aim of this study was to evaluate the mechanical chiseling effects on the soil bulk density (BD) and degree of compaction (DC) in a Rhodic Hapludox under NT, in different periods of time after tillage and in different soil layers.

\section{MATERIAL AND METHODS}

The study was carried out at the State University of Ponta Grossa (UEPG), Paraná State, Brazil $\left(25^{\circ} 05^{\prime} 52^{\prime \prime} \mathrm{S} ; 50^{\circ} 02^{\prime} 43^{\prime \prime} \mathrm{W} ; 1.080 \mathrm{~m}\right)$. The predominant climate in the region, according to the Köppen classification, is humid subtropical mesothermal $(\mathrm{Cfb})$, with annual means of $18.7^{\circ} \mathrm{C}$ and $1.600 \mathrm{~mm}$ rainfall (IAPAR, 2000). The soil in the study area is classified as a Rhodic Hapludox, (Latossolo Vermelho distrófico). The texture (Table 1) was determined according to the densimeter method (Gee \& Bauder, 1986) and particle density using a helium pycnometer (ACCUPYC 1330, Micromeritics Instrument Corporation $\left.{ }^{\circledR}\right)$.

Table 1. Particle size, organic carbon and particle density in the different evaluated layers of a Rhodic Hapludox before chiseling

\begin{tabular}{cccccc}
\hline Layer & Clay & Silt & Sand & $\mathbf{C}_{\text {org }}$ & $\rho_{\mathrm{S}}$ \\
\hline $\mathrm{m}$ & \multicolumn{4}{c}{$\mathrm{g} \mathrm{kg}^{-1}-\mathrm{g} \mathrm{cm}^{-3}$} \\
$0.0-0.10$ & 506.2 & 52.4 & 441.4 & 33.9 & 2.54 \\
$0.10-0.20$ & 518.4 & 53.3 & 428.3 & 28.3 & 2.58 \\
$0.20-0.30$ & 512.3 & 54.3 & 433.4 & 25.4 & 2.59 \\
$0.30-0.40$ & 520.5 & 54.4 & 425.1 & 22.8 & 2.60 \\
\hline
\end{tabular}

$\mathrm{C}_{\text {org }}$ : organic carbon; $\rho_{\mathrm{S}}$ : particle density of soil.

The study was performed in four experimental plots $\left(9 \times 50 \mathrm{~m}^{2}\right.$ each) under NT for 16 consecutive years. The following crop rotation was planted: maize (Zea mays L.) and soybean (Glycine max L.) in spring/summer and wheat (Triticum aestivum L.) in autumn/winter, intercropped with black oat (Avena strigosa Schreb) + vetch (Vicia sativa L.) as soil cover, also in crop rotation, preceding the maize crop. Soil tillage was performed using a chisel subsoiler with five parabolic shanks (three on the front bar and two on the rear bar), spaced $0.25 \mathrm{~m}$ apart, with chisel tips. The operation reached a depth of $0.25 \mathrm{~m}$ and the mean soil moisture at tilling was $0.29 \mathrm{~kg} \mathrm{~kg}^{-1}$, which was lower than the field capacity moisture $\left(0.38 \mathrm{~kg} \mathrm{~kg}^{-1}\right)$.

The following periods (treatments) were evaluated: no tillage (NT), immediately after chiseling (CHI), six months after chiseling (CHI6M) and one year after chiseling (CHI12M), in four layers: $0.0-0.10 ; 0.10-0.20 ; 0.20-0.30$; and 0.30 $0.40 \mathrm{~m}$. For each treatment, samples forty-eight (48) per plot were collected, at three randomized locations. In each location, undisturbed samples in $100 \mathrm{~cm}^{3}$ metal rings were collected using an electro-mechanical sampler, which enables sample collecting at different depths at the same location, without impact, with a constant speed for ring introduction in the soil of $2 \mathrm{~mm} \mathrm{~s}^{-1}$ (Figueiredo, 2010).

Samples were previously prepared and dried at $105^{\circ} \mathrm{C}$ for $24 \mathrm{~h}$. After the soil dry mass was obtained, the soil bulk density was determined (Blake \& Hartge, 1986). The degree of compaction (DC) was 
calculated through the following formula: DC = 100BD/BDref, where BD is the soil bulk density and BDref is the reference soil density, obtained through the application of a specific load or pressure.

The method used in order to obtain BDref was adapted from Håkansson (1990). For the BDref determination, rings (diameter $7 \mathrm{~cm}$, height $2.5 \mathrm{~cm}$ ) were filled with air-dried fine soil (ADFS) $(<2 \mathrm{~mm})$, with three replications per layer. The samples were water saturated for $24 \mathrm{~h}$ and then subjected to the uniaxial compression test at a pressure of $200 \mathrm{kPa}$. The compression time was $10 \mathrm{~min}$, which was long enough to eachive more than $99 \%$ of the maximum compaction (Silva et al., 2000). The BDref values of each evaluated layer are listed in figure 1. A consolidometer was used as described by Figueiredo et al. (2011), which pressure application is made through a pneumatic load. By the end of the test, the samples were placed in a heater at $105{ }^{\circ} \mathrm{C}$ for soil dry mass measurement.

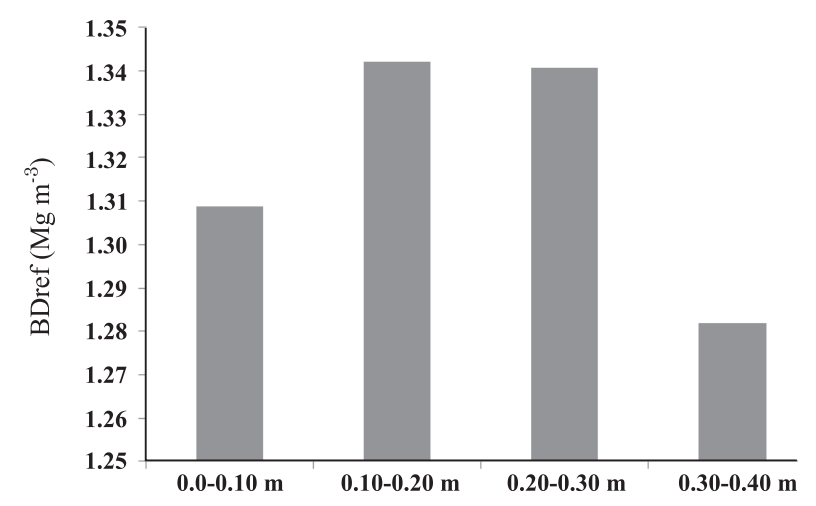

Figure 1. Reference soil density (BDref) values achieved through the uniaxial compression test performed of the evaluated layers of a Rhodic Hapludox under NT.

Daily rainfall data, used to define the wetting and drying cycles, were collected from a weather station located near the experimental area, at the UEPG. Each period, evaluated after chiseling, was considered a treatment and compared to the plots under no-tillage, without chiseling (NT). For the discrimination and comparison of the chiseling effects on BD and DC over time, the statistical criteria employed was the comparison of means using the mean confidence interval (Payton et al., 2000), whereby two periods are considered significantly different when there is no overlap between the upper and lower limits.

\section{RESULTS AND DISCUSSION}

The bulk density (BD) values for the soil under NT (Figure 2) fall into the normal range of clay soils, which can vary from 0.9 to $1.2 \mathrm{Mg} \mathrm{m}^{-3}$. There were no significant differences for the BD in the layers of $0.0-0.10,0.10-0.20$ and $0.20-0.30 \mathrm{~m}$, which were different from the $0.30-0.40 \mathrm{~m}$ layer, where a lower soil BD was verified. The $0.10-0.20 \mathrm{~m}$ layer showed a higher value of soil BD due to soil no-tillage and consequent accumulation of pressure applied by the machinery traffic and agricultural implements on the soil surface under NT over time (Suzuki et al., 2007).

There were no plant-growth limiting values of BD in the evaluated layers, as they remained under 1.30$1.40 \mathrm{Mg} \mathrm{m}^{-3}$, the threshold range considered critical for root growth in clay soils (Reichert et al., 2003). Cavalieri et al. (2009) observed, in a similar soil, a small BD increase due to the persistence of dense layers resulting from a different management prior to NT implementation. Long-term conservation managements result in a better behavior of the soil porous system and increase its stability. In the 0.0 $0.10 \mathrm{~m}$ layer, there was a significant BD decrease soon after chiseling (Figure 3). However, six months later, there was a $20 \% \mathrm{BD}$ increase, which remained stable for one year, tending to stabilize. The wetting and drying cycles are stronger in the soil surface layers $(0-20 \mathrm{~cm})$ due to the higher concentration of plant root systems and organic matter content (Horn \& Dexter, 1989) increasing resilience and helping the soil recover faster from a disturbance. Biological processes, such as root growth and microbial activities, also play an important regenerative role in soil compaction, especially in the soil surface layers (Gregory et al., 2007).

In the 0.10-0.20 m layer (Figure 3), the decreasing trend of BD was maintained, verified in the soil after 16 years of NT soon after chiseling, although it increased substantially six months later. However, 12 months after chiseling, the $\mathrm{BD}$ values were

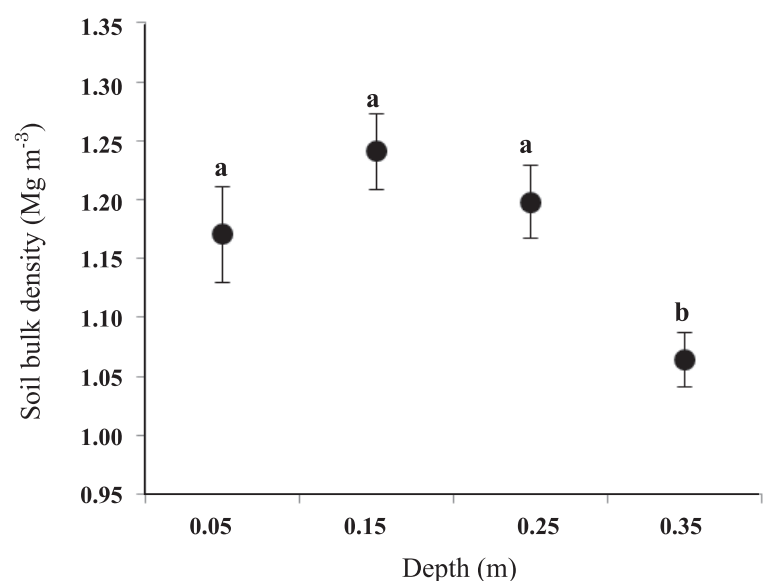

Figure 2. Mean values of soil density and respective confidence intervals before chiseling. Same letters indicate overlap of the confidence intervals at the different depths. 
similar to those observed before that operation, confirming the low effect of chiseling on the BD decrease. A feasible explanation would be the presence of a stronger resilience process in the soil. The soil physical resilience originates from a series of regenerative processes (Gregory et. al., 2007). The porosity of a highly resilient soil is recovered through expansion and contraction processes, caused by the natural wetting and drying cycles (Horn \& Dexter, 1989).

In the 0.20-0.30 $\mathrm{m}$ layer (Figure 3), there were no significant differences of BD between before and after chiseling, indicating that this layer was not efficiently mobilized. Six months after chiseling, the BD significantly increased, followed by a decrease after 12 months. These results are similar to those found by Araújo et al. (2004), who stated a reduction in structural soil quality after chiseling, increasing the resistance to penetration, i.e., affecting the soil structure negatively. The higher resilience of soils under NT may be due to reduced soil tillage favoring the accumulation of straw and organic matter (OM) in the surface layers (Blanco-Canqui et al., 2009, 2010).

In the deepest layer $(0.30-0.40 \mathrm{~m})$, the mean $\mathrm{BD}$ value before chiseling was $1.06 \mathrm{Mg} \mathrm{m}^{-3}$, which is fairly low for a layer at this depth (Figure 3), but common for the $\mathrm{B}$ horizon of Oxisols. This value also indicates that the stresses applied by the machinery had possibly not come to interfere with the soil structure of this layer. Immediately after chiseling,

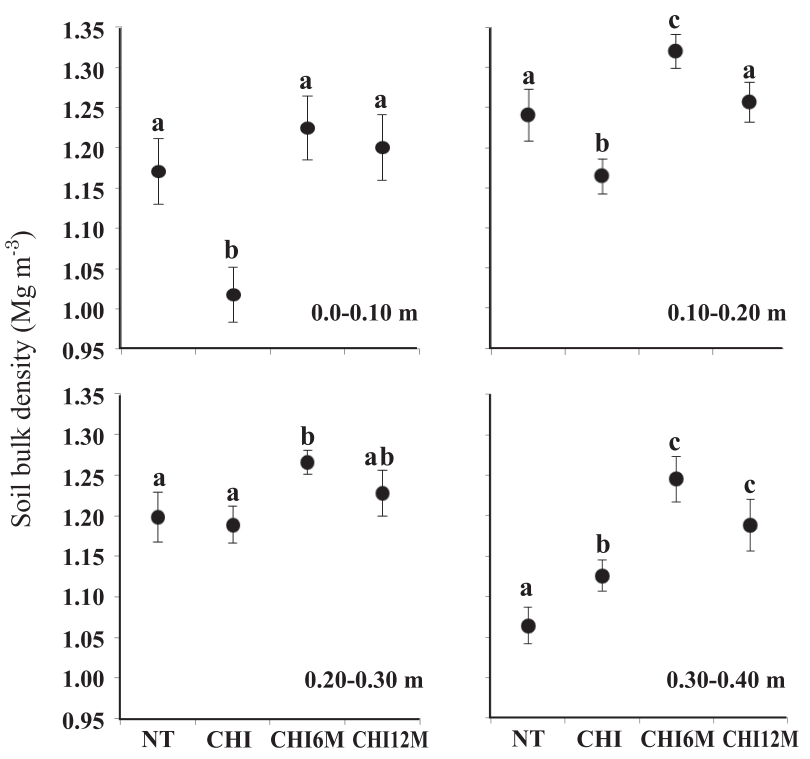

Figure 3. Mean values and respective confidence intervals for soil bulk density in the different sampling periods. NT: no-tillage before chiseling; CHI: immediately after chiseling; CHI6M: six months after chiseling; CHI12M: 12 months after chiseling. Same letters indicate overlap of the confidence intervals. there was an increment on this value, in spite of the expected decrease that had been verified in the other layers. After six months, the BD reached its maximum value for this layer $\left(1.25 \mathrm{Mg} \mathrm{m}^{-3}\right)$ with a small decrease at 12 months $\left(1.19 \mathrm{Mg} \mathrm{m}^{-3}\right)$. The BD increase in the subsurface may be attributed to the absence of compacted layers in the surface, caused through the chiseling process that increases the pressure transmission to the deeper layers (Veiga et al., 2007). The presence of a layer with a higher BD next to the surface $(0.10-0.20 \mathrm{~m}-$ Figure 2$)$ may form a protective barrier ("buffer") that prevents the transmission of the pressure applied at the surface to deeper soil layers. Thus, these results indicate that the possible beneficial effects of chiseling on the $\mathrm{BD}$ reduction in the soil surface increased the risk of compaction in the subsurface, at least in the short term. The intensity and frequency of the natural processes of compaction alleviation, such as soil wetting and drying cycles, is sharply reduced in the subsurface, which increases compaction persistence in the deeper layers (Hakånsson, 2005).

The influence of the wetting and drying cycles on $\mathrm{BD}$ can be seen in figure 4 . As the experiment was carried out in the field, the daily rainfall data were used as criteria for soil wetting. For the definition of a wetting and drying cycle, the field capacity (FC) concept was adopted, i.e., the field capacity is reached when the soil water content promptly decreases by drainage after a period of rain or irrigation and the water movement rate is very slow after two or three days (Brady \& Weil, 2007). Rainfall exceeding $20 \mathrm{~mm}$ was considered a wetting cycle and three days without rain a drying cycle.

In the period between chiseling, in May 2009, and sampling, in October 2009, around 10 wetting and drying cycles were verified. During one year, until the last sampling performed in May 2010, 25 wetting and drying cycles were observed. The BD decrease in the 0.10-0.20 m layer, between CHI6M and CHI12M, may be related to the existence of the wetting and drying cycles. According to Hakånsson (2005), these cycles may alleviate the compaction effects mainly on the surface layers. The BD increase, one year after chiseling, was also observed by Reichert et al. (2009) due to soil consolidation and the influence of the wetting and drying cycles in the internal soil structure. A higher rainfall accumulation also intensifies soil reconsolidation and reduces the chiseling effects, which may explain the BD increase until CHI6M.

The DC decreased after chiseling (88 to $76 \%$ ) in the $0.0-0.10 \mathrm{~m}$ layer, as observed in figure 5 . According to Suzuki et al. (2007), lower DC levels indicate that the soil is excessively loose, compromising water retention. Six months later, the DC increased from 76 to $92 \%$ and, after 12 months, there was a minor DC decrease that 

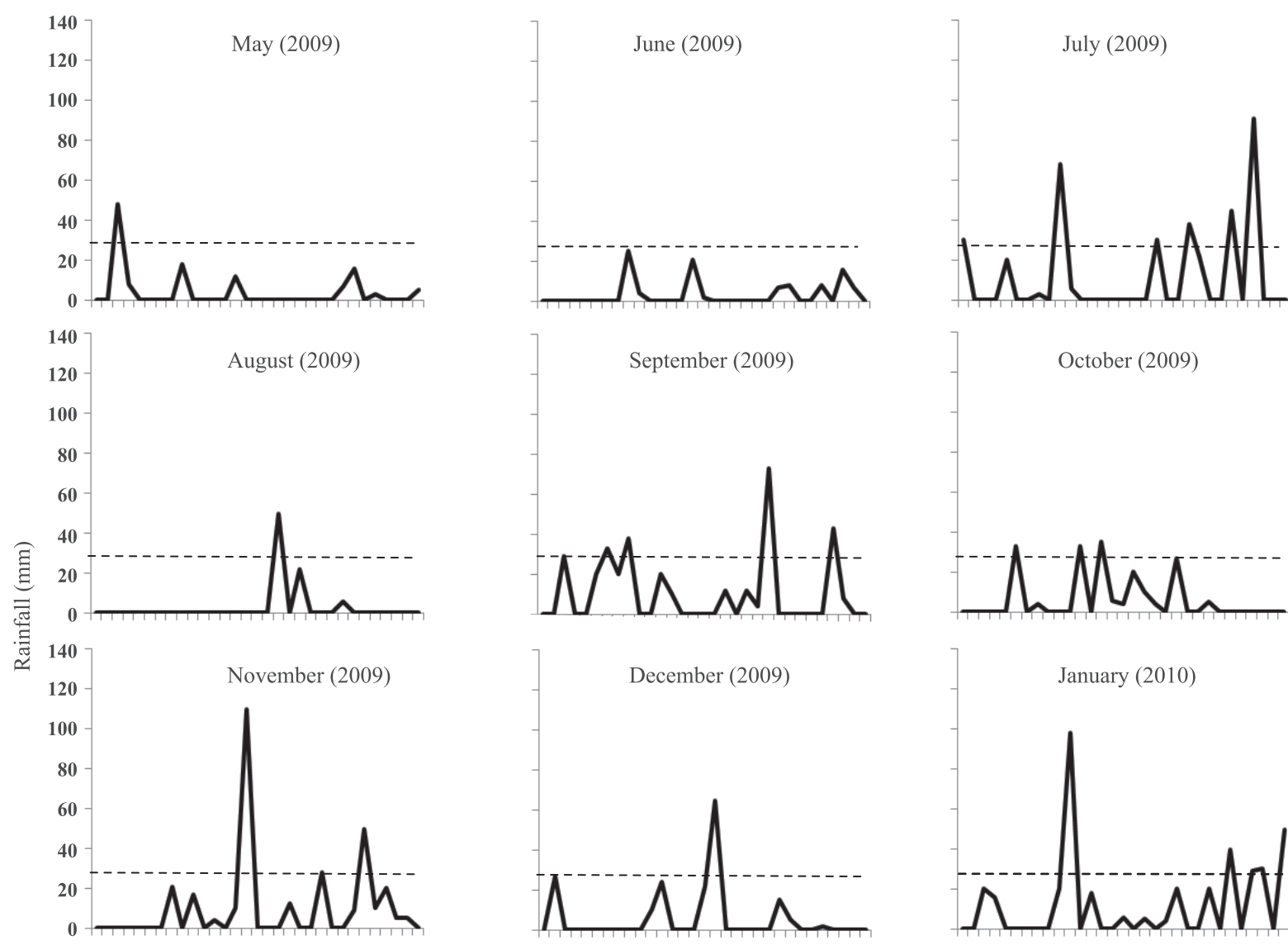

October (2009)
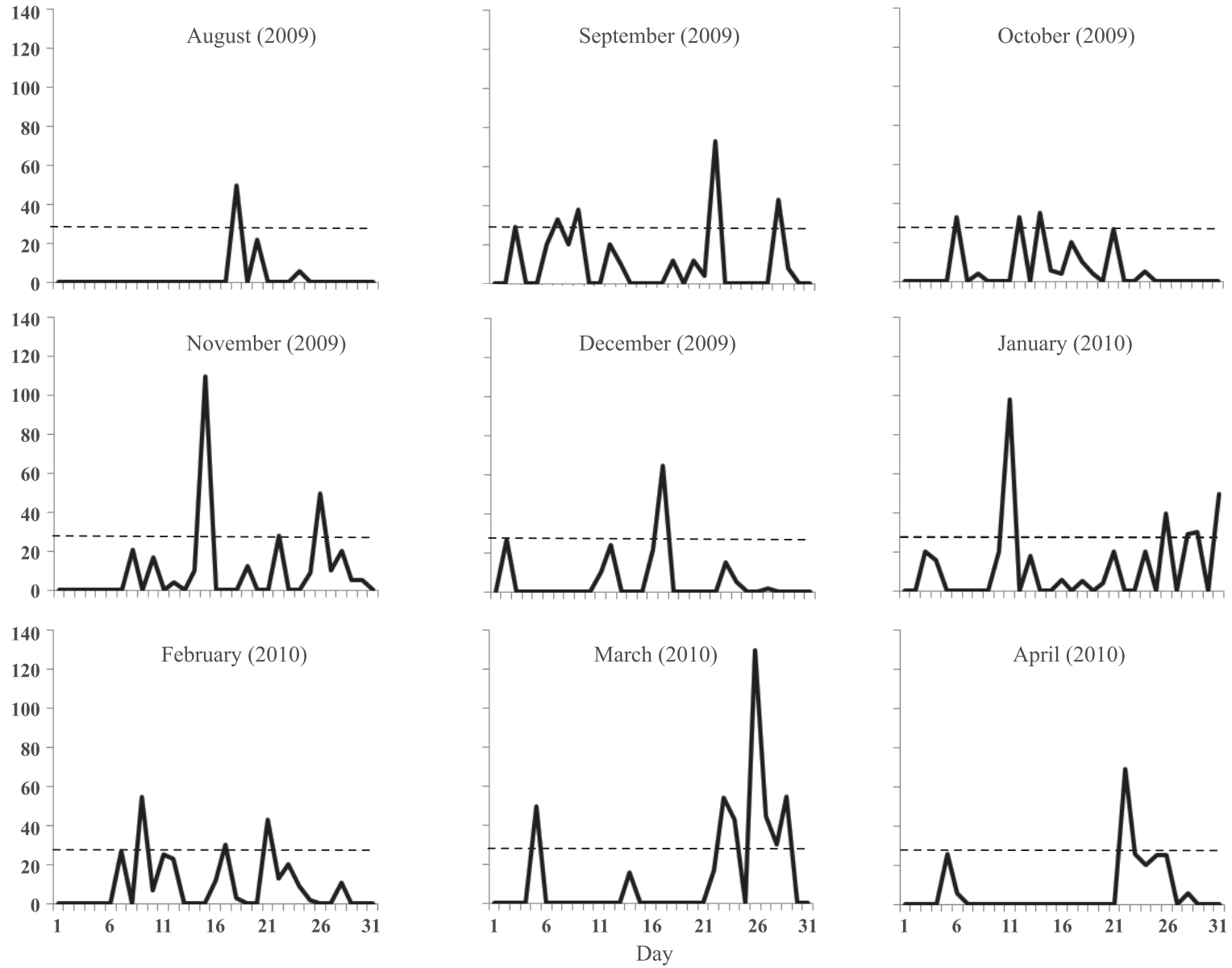

Figure 4. Daily rainfall during the experimental period. Peaks above the dotted line indicate the presence of wetting and drying cycles in the soil.

indicates the stabilization of the soil structure. The wide DC variation may have been caused by the soil consolidation due to rainfall accumulation and traffic of machinery. Furthermore, the higher intensity of wetting and drying cycles (Figure 4) and biological activity in the soil surface layer, especially crop root growth, contribute to accelerate soil recovery after mechanical interference (Busscher et al., 2002; Araújo et al., 2004), and establish regenerative processes of the soil structure.

In the $0.10-0.20 \mathrm{~m}$ layer, the decrease of DC (up to $86 \%$ ) was less intense immediately after chiseling than in the $0.0-0.10 \mathrm{~m}$ layer (Figure 5). The DC showed an increase of $21 \%$ after six months, reaching $97 \%$, which in the short and medium term may negatively affect crop yield. According to Håkansson (1990), Suzuki et al. (2007) and Reichert et al. (2009), the optimum DC range with highest levels of crop yield is between 80 and $90 \%$. One year after chiseling, the DC decreased to $92 \%$, which is the same value found for DC under NT. These results confirm the temporary chiseling effect and the great capacity of the soil for physical recovery or physical resilience under NT.

In the $0.20-0.30 \mathrm{~m}$ layer, the DC was not modified before or soon after chiseling (Figure 5). However, six months later, the DC showed a significant increment, which was reduced to $93 \%$, 
12 months after tillage. In all periods, the DC was evaluated above $90 \%$, representing an alert regarding compaction. In this layer, chiseling was not effective to reduce DC. On the other hand, the DC increase between CHI and CHI6M was similar to that in the $0.10-0.20 \mathrm{~m}$ layer (Figure 4). The loss of soil organic carbon may have contributed to such a significant increase, especially to the depth of $0.30 \mathrm{~m}$. In the $0.30-0.40 \mathrm{~m}$ layer, the DC tended to increase, reaching its maximum value of $95 \%$ six months after decompaction and decreasing to $90 \%$ after 12 months (Figure 5). Even with the evidence of stabilization, the DC increased by $11 \%$ when the periods before and 12 months after chiseling were compared. The 0.30-0.40 m layer was compacted most, since at the end of one year, the DC was still higher than before the operation. This DC increment may be associated to the effective transmission of loads applied to the soil during the experimental period due to the removal of more compressionresistant layers by soil tillage.

During the experimental period, the rainfall was intense (Figure 4) and, associated to the soil clayey texture, soil moisture reamined high for a longer period. The DC increase over the previous status could have been caused by a greater susceptibility of the very moist soil to plastic deformations (Gregory et al., 2007), under the machinery traffic and other processes that promote soil reconsolidation.
In soils under NT, the tillage absence, combined with the continuous machinery traffic, favors the accumulation of the compaction effects; however, this situation seems to be partly balanced because of the higher stability of the complex of macropores which, after a long period of NT system, together with an appropriate management, results in a dynamic equilibrium in the natural processes of soil compaction and decompaction (Håkansson, 2005). Furthermore, according to Blanco-Canqui et al. (2009), the continuous carbon supply under NT on the surface reduces soil susceptibility to compaction. Nevertheless, surface compaction was observed in NT soils, mainly in the layer from 0.10 to approximately $0.30 \mathrm{~m}$, which is confirmed by this research, where the highest $\mathrm{DC}$ values were found at this depth range. Regarding the DC, it is important to highlight that the $\mathrm{DC}$ values resulting from the Proctor test, used to calculate the BDref, were higher than those from the uniaxial compression test and those originally calculated by the methodology described by Håkansson (1990).

The results indicate that the $\mathrm{DC}$ values showed high temporal variability in this soil and that DC $>90 \%$ was only partly found during the experimental period. Also, the DC tends to decrease at CHI6M, indicating a stabilization around the original DC values, especially in the layers down to $30 \mathrm{~cm}$. Considering that the uniaxial compression
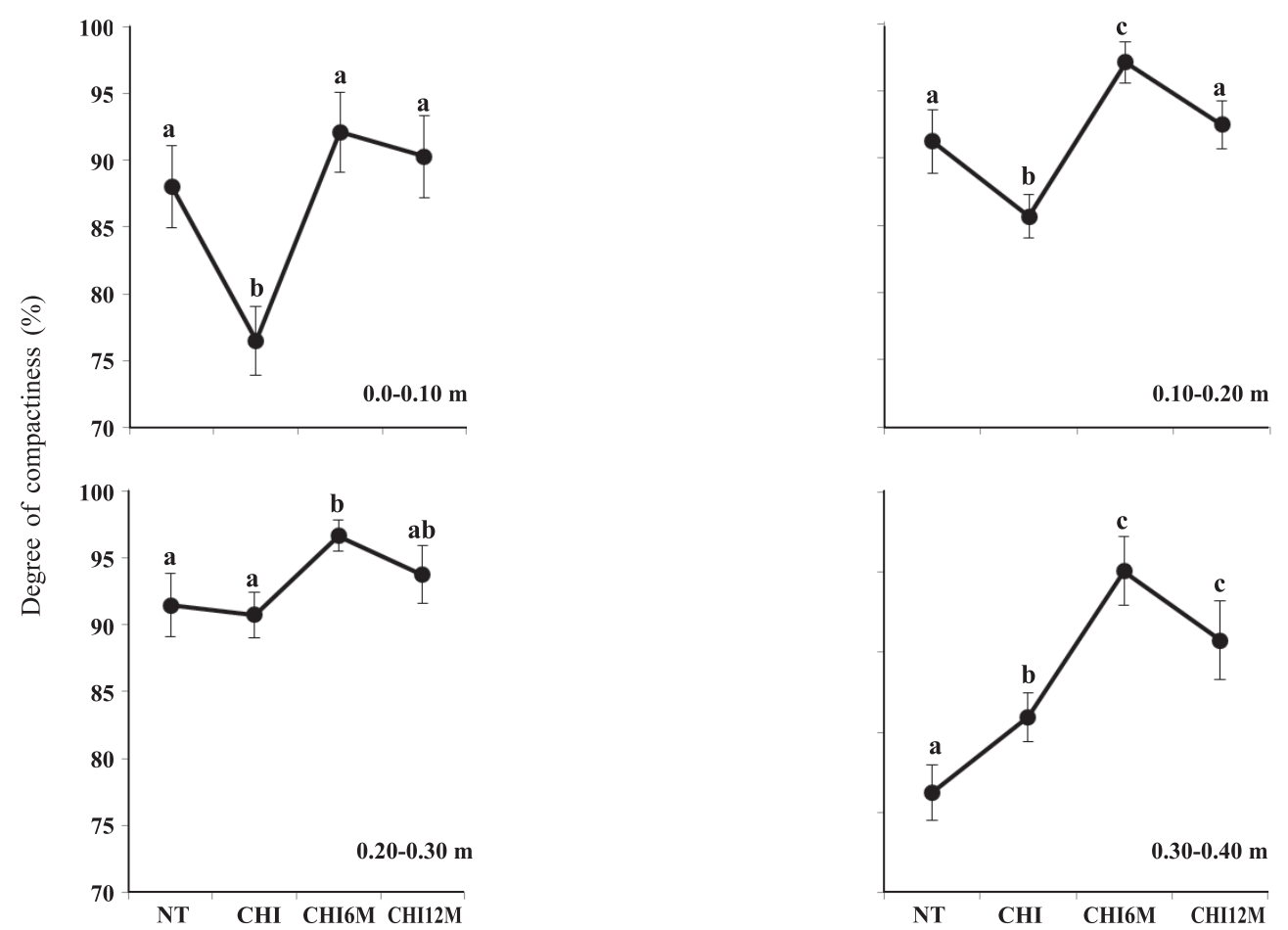

Figure 5. Mean values and respective confidence intervals for the degree of compaction in the different sampling periods. NT: no-tillage before chiseling; CHI: immediately after chiseling; CHI6M: six months after chiseling; CHI12M: 12 months after chiseling. Same letters indicate overlap of the confidence intervals. 
test was used to establish the DC, it is suggested that no evidence of intense compaction was found, as the DC values range around $90 \%$. According to Reichert et al. (2009), this value is still below the compaction threshold that would affect plant growth. In a Rhodic Hapludox under NT that was chiseled, Klein et al. (2009) used the Proctor test to determine the DC and affirmed that the soil physical conditions become limiting to full plant development when the DC values are above $85 \%$. The studied soil seems to be more tolerant to higher DC values, which suggests that the optimum value varies according to the local soil and water regime. Values of the DC may be detrimental to crop yield according to some characteristics, such as soil type, climate, species sensitivity and the environment itself. The results show that the chiseling efficacy was partial and temporary due to fast soil reconsolidation since, within one year, the DC values found for the layers down to a depth of $0.30 \mathrm{~m}$ were not different from those in soils under permanent no-tillage. The requirement of monitoring the moisture conditions for machinery traffic is decisive to avoid the evolution of compaction and the eventual loss of the physical quality of soils under NT.

\section{CONCLUSIONS}

1. In the short analysis period, the chiseling of soils under NT reduced BD and DC; however, there was an increment in these variables six months later.

2. After six months, no chiseling effects were observed on BD or DC.

3. Both $\mathrm{BD}$ and the $\mathrm{DC}$ increased in the subsurface after chiseling, so its possible beneficial effects on BD reduction in the soil surface increase the risk of soil compaction in the subsurface, at least in the short term.

\section{LITERATURE CITED}

ARAÚJO, M.A.; TORMENA, C.A.; INOUE, T.T. \& COSTA, A.C.S. Efeitos da escarificação na qualidade física de um Latossolo Vermelho distroférrico após treze anos de semeadura direta. R. Bras. Ci. Solo, 28:495-504, 2004.

BLAKE, G.R.\& HARTGE, K.H. Bulk density. In: KLUTE, A., ed. Methods of soil analysis. 2.ed. Madison, American Society of Agronomy, 1986. p.363-375.

BLANCO-CANQUI, H.; STONE, L.R.; SCHLEGEL, A.J.; BENJAMIN, J.G.; VIGIL, M.F. \& STAHLMAN, P.W. Continuous cropping systems reduce near-surface maximum compaction in no-till soils. Agron. J., 102:1217$1225,2010$.
BLANCO-CANQUI, H.; STONE, L.R.; SCHLEGEL, A.J.; LYON, D.J.; VIGIL, M.F.; MIKHA, M.M.; STAHLMAN, P.W. \& RICE, C.W. No-till induced increase in organic carbon reduces maximum bulk density of soils. Soil Sci. Soc. Am. J., 73:1871-1879, 2009.

BRADY, N.C. \& WEIL, R.R. The nature and properties of soils. 14.ed. New Jersey, Prentice-Hall, 2007. 980p.

BUSSCHER, W.J.; BAUER, P.J. \& FREDERICK, J.R. Recompaction of a coastal loamy sand after deep tillage as a function of subsequent cumulative rainfall. Soil Till. Res., 68:49-57, 2002.

CAMARA, R.K. \& KLEIN, V.A. Escarificação em plantio direto como técnica de conservação do solo e da água. R. Bras. Ci. Solo, 29:789-796, 2005.

CAVALIERI, K.M.V.; SILVA, A.P.; TORMENA, C.A.; LEÃO, T.P.; DEXTER, A.R. \& HÅKANSSON, I. Long-term effects of no-tillage on dynamic soil physical properties in a Rhodic Ferrasol in Paraná, Brazil. Soil Till. Res., 103:158-164, 2009.

FIGUEIREDO, G.C. Avanços metodológicos e instrumentais em física do solo. Piracicaba, Escola Superior de Agricultura "Luiz de Queiroz", 2010. 163p. (Tese de Doutorado)

FIGUEIREDO, G.C.; SILVA, A.P.; TORMENA, C.A.; GIAROLA, N.F.B.; MORAES, S.O. \& ALMEIDA, B.G. Desenvolvimento de um consolidômetro pneumático: Modelagem da compactação, penetrometria e resistência tênsil de agregados de solo. R. Bras. Ci. Solo, 35:389-402, 2011.

GEE, G.W. \& BAUDER, J.W. Particle-size analysis. In: KLUTE, A., ed. Methods of soil analysis. Part 1. Physical and mineralogical methods. 2.ed. Madison, American Society of Agronomy, Soil Science Society of America, 1986. p.383-411. (Agronomy Series, 9)

GREGORY, A.S.; WATTS, C.W.; WHALLEY, W.R.; KUAN, H.L.; GRIFFITHS, B.S.; HALLETT, P.D. \& WHITMORE, A.P. Physical resilience of soil to field compaction and the interactions with plant growth and microbial community structure. Europ. J. Soil Sci., 58:1221-1232, 2007.

HÅKANSSON, I. A method for characterizing the state of compactness of the plough layer. Soil Till. Res., 16:105$120,1990$.

HÅKANSSON, I. Machinery-induced compaction of arable soils: incidence - consequences - counter-measures. Uppsala, Division of Soil Management, 2005. 154p. (Reports from the Division of Soil Management, 109)

HÅKANSSON, I. \& LIPIEC, J. A review of the usefulness of relative bulk density values in studies of soil structure and compaction. Soil Till. Res., 53:71-85, 2000.

HORN, R. \& DEXTER, A.R. Dynamics of soil aggregation in an irrigated desert loess. Soil Till. Res., 13:253-266, 1989.

INSTITUTO AGRONÔMICO DO PARANÁ - IAPAR. Cartas climáticas do Paraná: Edição ano 2000, versão 1.0. Londrina, 2000. CD ROM.

KLEIN, V.A.; BASEGGIO, M. \& MADALOSSO, T. Indicadores da qualidade física de um Latossolo Vermelho distrófico típico sob plantio direto escarificado. Ci. Rural, 39:24752481, 2009. 
LIPIEC, J.; HÅKANSSON, I.; TARKIEWICZ, S. \& KOSSOWSKI, J. Soil physical properties and growth of spring barley as related to the degree of compaction of two soils. Soil Till. Res., 19:307-317, 1991.

MATERECHERA, S.A.; DEXTER, A.R. \& ALSTON, A.M. Formation of aggregates by plant-roots in homogenized soils. Plant Soil, 142:69-79, 1992.

OLIVEIRA, T.S.; COSTA, L.M.; REGAZZI, A.J. \& FIGUEIREDO, M.S. Efeito de ciclos de umedecimento e secagem sobre a estabilidade de agregados em água de quatro Latossolos brasileiros. R. Bras. Ci. Solo, 20:509-515, 1996.

PAYTON, M.E.; MILLER, A.E. \& RAUN, W.R. Testing statistical hypotheses using standard error bars and confidence intervals. Comm. Soil Sci. Plant Anal., 31:547-551, 2000.

REICHERT, J.M.; KAISER, D.R.; REINERT, D.J. \& RIQUELME, U.F.B. Variação temporal de propriedades físicas do solo e crescimento radicular de feijoeiro em quatro sistemas de manejo. Pesq. Agropec. Bras., 44:310-319, 2009.

REICHERT, J.M.; REINERT, D.J. \& BRAIDA, J.A. Qualidade dos solos e sustentabilidade de sistemas agrícolas. Ci. Amb., 27:29-48, 2003.

REICHERT, J.M.; SUZUKI, L.E.A.S.; REINERT, D.J.; HORN, R. \& HÅKANSSON, I. Reference bulk density and critical degree of compaction for no-till crop production in subtropical highly weathered soils. Soil Till. Res., 102:242$254,2009$.
SEYBOLD, C.A.; HERRICK, J.E. \& BREJDA, J.J. Soil resilience: A fundamental component of soil quality. Soil Sci., 164:224234, 1999.

SILVA, A.P.; KAY, B.D. \& PERFECT, E. Management versus inherent soil properties effects on bulk density and relative compaction. Soil Till. Res., 44:81-93, 1997.

SILVA, V.R.; REINERT, D.J. \& REICHERT, J.M. Susceptibilidade à compactação de um Latossolo Vermelho-Escuro e de um Podzólico Vermelho-Amarelo. R. Bras. Ci. Solo, 24:239$249,2000$.

SUZUKI, L.E.A.S.; REICHERT, J.M.; REINERT, D.J. \& LIMA, C.L.R. Grau de compactação, propriedades físicas e rendimento de culturas em Latossolo e Argissolo. Pesq. Agropec. Bras., 42:1159-1167, 2007.

VEIGA, M.; REINERT, D.J.; REICHERT, J.M. \& KAISER, D.R. Short and long-term effects of tillage systems and nutrient sources on soil physical properties of a southern Brazilian Hapludox. R. Bras. Ci. Solo, 32:1437-1446, 2008.

XU, D. \& MERMOUD, A. Topsoil properties as affected by tillage practices in North China. Soil Till. Res., 60:11-19, 2001. 
